\title{
The past 800 ka viewed through Antarctic ice cores
}

\author{
British Antarctic Survey, High Cross, Madingley Road, Cambridge, CB3 0ET, UK.Email: ewwo@bas.ac.uk
}

\begin{abstract}
The later parts of the Quaternary are of particular importance for assessing our ability to understand the future operation of the Earth because the main boundary conditions are similar to those of today, and because we have a density of data that allows hypotheses to be tested rigorously. An important source of such data is Antarctic ice cores, now extending back $800 \mathrm{ka}$, and containing signals both of climate, and of climate forcing factors. The Antarctic ice core deuterium record, representing Antarctic temperature, is one of the iconic Quaternary records. It shows, in common with other palaeoclimate records such as the marine benthic isotope stack, a dominant 100 ka periodicity of short warm interglacials and long, cold, glacial periods. There appear to be two different styles of interglacial. Within the glacials a millennial scale variability is dominant, manifested as the rapid Dansgaard-Oeschger events in the north, and as subdued out-of-phase counterparts in the south. The trace gases, carbon dioxide and methane, also show a remarkably similar pattern to that of the climate records. They certainly played a role in amplifying small changes in insolation into large climate swings, and their signals are diagnostic of the operation of different processes in the ocean and the terrestrial biosphere.
\end{abstract}

\section{Introduction}

The later parts of the Quaternary have two major advantages for those who want to learn about how the Earth and its climate may evolve in the near future. Firstly, this time provides examples of the operation of a range of processes under boundary conditions (especially the configuration of the continents and of ocean gateways) similar to those of today. Secondly, we have access to much more detailed records of what actually occurred than can be obtained for earlier times. Probably the most potent example of this is the ice cores. They exist only for this period (stretching back now $800 \mathrm{ka}$ in Antarctica (Jouzel et al., 2007) and $123 \mathrm{ka}$ in Greenland (North Greenland Ice Core Project Members, 2004), and they contain not only a climate record for their region, but also concurrent data on climate forcings (especially of greenhouse gases) that have a global reach.

Ice cores can be considered to hold information in three distinct forms. Firstly the isotopic content of the water molecules themselves acts as a proxy for the local temperature above the drilling site. Secondly, many impurities, including aerosol particles and soluble trace gases, are trapped in falling snow or at the snow surface: in this part of the record for example, one can find short spikes of elevated sulfuric acid concentrations corresponding to the years of powerful volcanic eruptions. Finally, snow turns to solid ice in these regions only by sintering under the weight of overlying layers. When this occurs (perhaps 60-100 m below the surface) samples of air are closed off as bubbles that can subsequently be re-opened in order to sample the stable trace gases that were in the atmosphere at the time.

\section{EPICA Dome $\mathrm{C}$ and other ice cores}

For many years, the oldest ice core record available was the one from Vostok (Petit et al., 1999), collected by Russian, French and US scientists and engineers, and extending back $420 \mathrm{ka}$. However, the European Project for Ice Coring in Antarctica (EPICA) recently completed the drilling of two ice cores (EPICA Community Members, 2004; EPICA Community Members, 2006), one of which (Dome C) extends the record to $800 \mathrm{ka}$. In their common parts, Vostok and Dome $\mathrm{C}$ (which are about $500 \mathrm{~km}$ apart) show almost identical records, and this statement can be extended across the continent to Dome Fuji (Watanabe et al., 2003), where a Japanese team is currently extending the record. Because it is the longest (in age) single record, the rest of this article will concentrate on the data from Dome C.

A critical issue in ice core science (as in other areas of geoscience) is to establish an age scale for the ice. For ice cores in areas with a high snow accumulation rate, it is generally possible to count annual layers using properties that show a regular seasonal cycle. However, of necessity, the cores that span the longest time periods come from regions with very low snow accumulation rates, where this is not possible. At Dome $\mathrm{C}$, the dating is achieved using a physically-based model of snow accumulation and ice thinning rates, constrained and modified by a set of known dates. These constraints derive from a range of sources, culminating in the radiometric date for the Brunhes-Matuyama magnetic reversal, which is represented in the ice core by a peak in concentration of the isotope ${ }^{10} \mathrm{Be}$ (Raisbeck et al., 2006). The current (EDC3) age scale is described in a series of papers and a summary paper (Parrenin et al., 2007).

\section{The Antarctic climate record}

The Antarctic deuterium record for the past $800 \mathrm{ka}$ is shown in Figure 1, along with an estimate of Antarctic temperature derived from it (Jouzel et al., 2007), and the classic benthic marine oxygen isotope stack (Lisiecki and Raymo, 2005). The latter record represents a combination of the oxygen isotope content of the ocean (which is controlled by global ice volume), and the fractionating effects of incorporation into shells (which is controlled by deepwater temperature).

The most obvious feature of the past $800 \mathrm{ka}$ is that climate (as represented in both ice and ocean) has a variability dominated by the occurrence of relatively short warm interglacial periods approximately every $100 \mathrm{ka}$. The Holocene (which we are in now) is the latest of these interglacials. The similarity between the records shows that at these long climate periods we are seeing a global climate signal: when there is more ice in the world, predominantly over North America and Eurasia, there are also colder temperatures in Antarctica. The origin of the $100 \mathrm{ka}$ cyclicity is widely believed to be related to astronomical cycles (Milankovich and related theories) (e.g., Imbrie et al., 1993). However, it remains a matter of debate why the relatively weak 100 ka period is seen more strongly than the precessional (around $20 \mathrm{ka}$ ) and obliquity (41 ka) signals that cause 


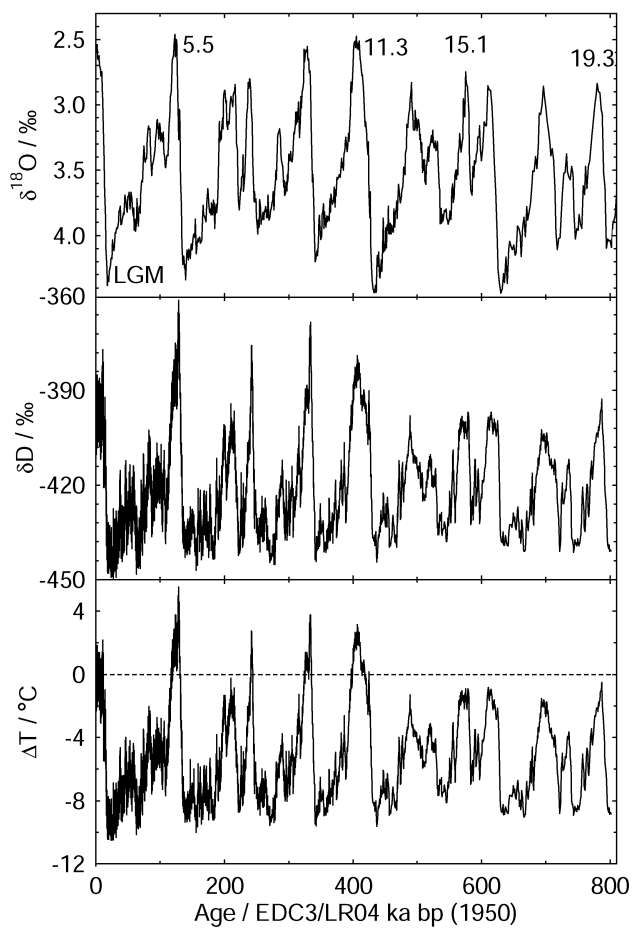

Figure 1 Top panel: Marine benthic oxygen isotope stack on LRO4 age scale (Lisiecki and Raymo, 2005); lower panels: 800 ka record, on EDC3 age scale, of deuterium, and temperature (difference from the last millennium, derived using a correction for seawater isotopic content and modelled ice sheet altitude) (Jouzel et al., 2007). Numbers above the marine curve represent selected MIS (marine isotope stages).

larger changes to insolation; and the mechanisms that amplify a small insolation change into a large climate change are also much debated.

Whatever the origin of the 100 ka cyclicity, it is not the case that every cycle is the same. The ice core record has particularly highlighted the differences between different interglacial periods. The 4 interglacials before $450 \mathrm{kyr}$ appear weaker than those that follow, whereas the glacial maxima have less variability in the Antarctic record. The interval between warm periods is also not uniform. No clear explanation for the change in style of interglacial around $450 \mathrm{ka}$ ago has yet emerged (Jouzel et al., 2007).

A final feature that is clear from the Antarctic record is the existence of millennial scale variability, particularly within the glacial periods. The signal has been shown (EPICA Community Members, 2006) to be closely associated with the larger millennial scale variability observed in Greenland (North Greenland Ice Core Project Members, 2004) and other northern hemisphere records, the socalled Dansgaard-Oeschger (D-O) events. These events of rapid warming (more than $10^{\circ}$ within decades in Greenland) seem to occur at the apex of slower Antarctic warmings; once Greenland climate has jumped, Antarctic temperature slowly falls again. This pattern has been considered diagnostic of changes in ocean heat transport, with the Southern Ocean building up heat during periods when the heat is not transported northwards (Stocker and Johnsen, 2003). Whatever the cause, this pattern of millennial scale variability is the dominant feature seen in climate records at timescales below those of the orbital cycles.

\section{Trace gases and other signals}

As already stated, a unique feature of ice cores is that they contain a direct record of the trace gas content of the atmosphere. $\mathrm{CO}_{2}$ is obviously a crucial gas for radiative forcing, but is also a diagnostic of

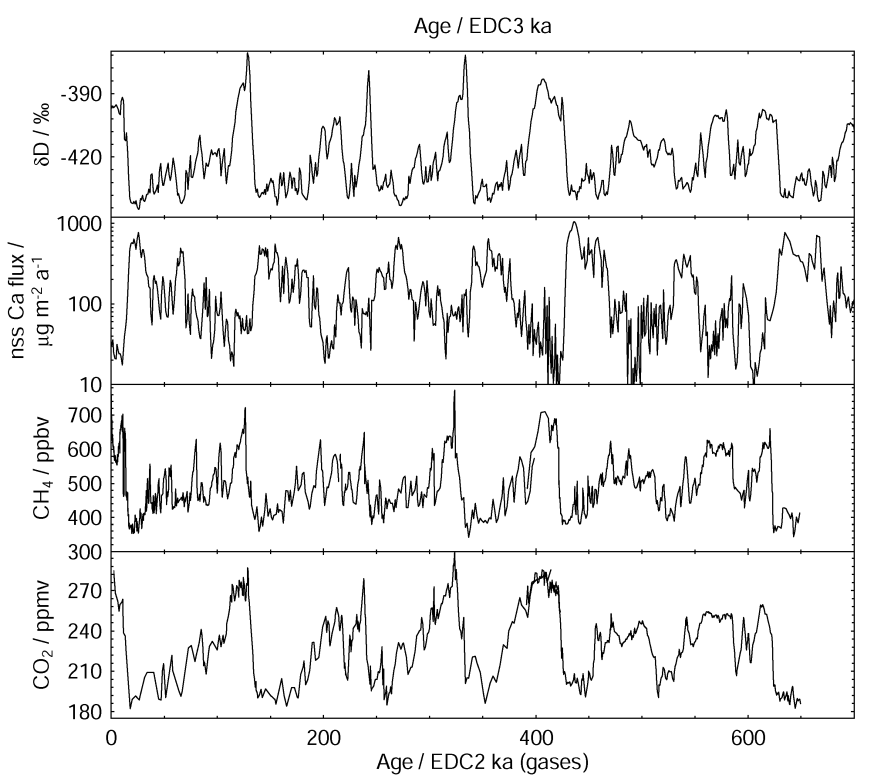

Figure 2 Records of deuterium, non-sea-salt calcium flux (Wolff et al. 2006), $\mathrm{CO}_{2}$ (Siegenthaler et al. 2005), and $\mathrm{CH}_{4}$ (Spahni et al. 2005) measured at Dome $C$. Note that there may be small timing mismatches because the gases are shown on the EDC2 age scale while the other records are on EDC3.

whether we understand the carbon cycle and the oceans that host many aspects of it. $\mathrm{CH}_{4}$ is another important greenhouse gas, and is also indicative of whether we have correctly assessed aspects of the terrestrial environment. Both gases have so far been reported for the past $650 \mathrm{ka}$ (Figure 2). At the time of writing, the records to $800 \mathrm{ka}$ are being prepared, and tied to the new EDC3 age scale. However, here I show the published data, which are on the old EDC2 age scale and can therefore not be compared directly to the climate record. $\mathrm{CO}_{2}$ particularly shows (Siegenthaler et al. 2005) a remarkable similarity to Antarctic temperature, with both the glacial-interglacial changes, and the same pattern of interglacials. The $\mathrm{CO}_{2}$ concentration is typically $280-300$ ppmv in warm interglacials, and only $240-$ 250 ppmv in "weak" interglacials. $\mathrm{CH}_{4}$ also shows (Spahni et al. 2005) a similar pattern, but with a much greater variability at millennial scale within glacial periods, because $\mathrm{CH}_{4}$ shows up D-O events.

The similarity of $\mathrm{CO}_{2}$ to Antarctic temperature (without the characteristics more reminiscent of the north) strongly suggests that the Southern Ocean exerts the main control on glacial-interglacial $\mathrm{CO}_{2}$ changes, although a wide range of physical and biogeochemical processes are still mooted to explain the signal (Archer et al., 2000). Both gases, but particularly $\mathrm{CO}_{2}$, probably played a significant role in amplifying the small externally-derived insolation changes into the large climate swings that are seen.

It is difficult to derive an exact phasing between changes in temperature and changes in $\mathrm{CO}_{2}$, because the age of the trapped gas is different from that of the ice that surrounds it. However, for the warming transitions into interglacials, the best estimate (although currently under scrutiny) is that the start of the $\mathrm{CO}_{2}$ increase lags temperature by around $800 \pm 600$ years (e.g., Monnin et al., 2001). Because the preceding statement is often misunderstood, it is important to emphasise that the increase in $\mathrm{CO}_{2}$ and temperature at each termination lasts for around $5 \mathrm{ka}$. For most of this period, both are rising in parallel, consistent with the idea that, after a small increase in temperature caused by external factors, the two parameters formed an amplifier in positive feedback, with the temperature causing a lagged increase in $\mathrm{CO}_{2}$, and the $\mathrm{CO}_{2}$ acting to increase the temperature further.

Many other parameters can be measured on ice cores (as indeed on marine and terrestrial records covering the same period). These give information on aspects of the environment such as sea ice, ocean biogeochemistry and dust transport (Wolff et al., 2006). In 
Figure 2, we have included as an example the non-sea-salt Ca flux, which is an indicator of the flux of dust deriving from South America: this record is an important input for studies of dust radiative forcing, and the effects of iron fertilisation of the ocean.

\section{Conclusion}

Ice cores are a key data source for the later parts of the Quaternary, providing an anchor of Antarctic temperature and some of the most important forcings. These data, when combined with data from other archives, make this time period highly amenable to modelling and hypothesis testing. The ice core community has formulated ambitious plans for future studies encompassing a range of timescales (Brook and Wolff, 2006). One part of this would aim to find a site where the ice core record could be extended to perhaps $1.5 \mathrm{Ma}$, and into the section (clearly seen in the marine record) where the $100 \mathrm{ka}$ cycles give way to 40 ka periodicity. Understanding the reason for this change is a key issue in Quaternary science, and discovering how $\mathrm{CO}_{2}$ and Antarctic climate changed during the transition is widely assumed to be a crucial part of the answer.

\section{References}

Archer, D., Winguth, A., Lea, D., and Mahowald, N., 2000, What caused the glacial/interglacial atmospheric $\mathrm{pCO}(2)$ cycles?: Reviews of Geophysics, v. 38, pp. $159-189$.

Brook, E., and Wolff, E. W., 2006, The future of ice core science: EOS Transactions, v. 87, pp. 39

EPICA Community Members, 2004, Eight glacial cycles from an Antarctic ice core: Nature, v. 429, pp. 623-628.

-, 2006, One-to-one hemispheric coupling of millennial polar climate variability during the last glacial: Nature, v. 444, pp. 195-198.

Imbrie, J., Berger, A., Boyle, E. A., Clemens, S. C., Duffy, A., Howard, W. R., Kukla, G., Kutzbach, J., Martinson, D. G., McIntyre, A., Mix, A. C., Molfino, B., Morley, J. J., Peterson, L. C., Pisias, N. G., Prell, W. L., Raymo, M. E., Shackleton, N. J., and Toggweiler, J. R., 1993, On the structure and origin of major glaciation cycles. 2. the 100,000-year cycle: Paleoceanography, v. 8, pp. 699-735.

Jouzel, J., Masson-Delmotte, V., Cattani, O., Dreyfus, G., Falourd, S., Hoffmann, G., Nouet, J., Barnola, J. M., Chappellaz, J., Fischer, H., Gallet, J. C., Johnsen, S., Leuenberger, M., Loulergue, L., Luethi, D., Oerter, H., Parrenin, F., Raisbeck, G., Raynaud, D., Schwander, J., Spahni, R., Souchez, R., Selmo, E., Schilt, A., Steffensen, J. P., Stenni, B., Stauffer, B., Stocker, T., Tison, J.-L., Werner, M., and Wolff, E. W., 2007, Orbital and millennial Antarctic climate variability over the last 800000 years: Science, v. 317, pp. 793-796.

Lisiecki, L. E., and Raymo, M. E., 2005, A Pliocene-Pleistocene stack of 57 globally distributed benthic $\delta^{18} \mathrm{O}$ records: Paleoceanography, v. 20, pp. PA1003; doi:10.1029/2004PA001071.

Monnin, E., Indermuhle, A., Dallenbach, A., Fluckiger, J., Stauffer, B., Stocker, T. F., Raynaud, D., and Barnola, J. M., 2001, Atmospheric $\mathrm{CO}_{2}$ concentrations over the last glacial termination: Science, v. 291, pp. $112-114$.

North Greenland Ice Core Project Members, 2004, High-resolution record of Northern Hemisphere climate extending into the last interglacial period: Nature, v. 431, pp. 147-151.
Parrenin, F., Barnola, J. M., Beer, J., Blunier, T., Castellano, E., Chappellaz, J., Dreyfus, G., Fischer, H., Fujita, S., Jouzel, J., Kawamura, K., Lemieux, B., Loulergue, L., Masson-Delmotte, V., Narcisi, B., Petit, J. R., Raisbeck, G., Raynaud, D., Ruth, U., Schwander, J., Severi, M., Spahni, R., Steffensen, J. P., Svensson, A., Udisti, R., Waelbroeck, C., and Wolff, E. W., 2007, The EDC3 chronology for the EPICA Dome C ice core: Climate of the Past, v. 3, pp. 485-497.

Petit, J. R., Jouzel, J., Raynaud, D., Barkov, N. I., Barnola, J. M., Basile, I., Bender, M., Chappellaz, J., Davis, M., Delaygue, G., Delmotte, M., Kotlyakov, V. M., Legrand, M., Lipenkov, V. Y., Lorius, C., Pepin, L., Ritz, C., Saltzman, E., and Stievenard, M., 1999, Climate and atmospheric history of the past 420,000 years from the Vostok ice core, Antarctica: Nature, v. 399, pp. 429-436.

Raisbeck, G. M., Yiou, F., Cattani, O., and Jouzel, J., 2006, 10Be evidence for the Matuyama-Brunhes geomagnetic reversal in the EPICA Dome C ice core: Nature, v. 444, pp. 82-84.

Siegenthaler, U., Stocker, T. F., Monnin, E., Luthi, D., Schwander, J., Stauffer, B., Raynaud, D., Barnola, J. M., Fischer, H., Masson-Delmotte, V., and Jouzel, J., 2005, Stable carbon cycle-climate relationship during the late Pleistocene: Science, v. 310, pp. 1313-1317.

Spahni, R., Chappellaz, J., Stocker, T. F., Loulergue, L., Hausammann, G., Kawamura, K., Flückiger, J., Schwander, J., Raynaud, D., Masson-Delmotte, V., and Jouzel, J., 2005, Atmospheric methane and nitrous oxide of the late Pleistocene from Antarctic ice cores: Science, v. 310, pp. 1317-1321.

Stocker, T. F., and Johnsen, S. J., 2003, A minimum thermodynamic model for the bipolar seesaw: Paleoceanography, v. 18, pp. art. no.-1087.

Watanabe, O., Jouzel, J., Johnsen, S., Parrenin, F., Shoji, H., and Yoshida, N., 2003, Homogeneous climate variability across East Antarctica over the past three glacial cycles: Nature, v. 422, pp. 509-512.

Wolff, E. W., Fischer, H., Fundel, F., Ruth, U., Twarloh, B., Littot, G. C., Mulvaney, R., Rothlisberger, R., de Angelis, M., Boutron, C. F., Hansson, M., Jonsell, U., Hutterli, M. A., Bigler, M., Lambert, F., Kaufmann, P., Stauffer, B., Stocker, T. F., Steffensen, J. P., Siggaard-Andersen, M. L., Udisti, R., Becagli, S., Castellano, E., Severi, M., Wagenbach, D., Barbante, C., Gabrielli, P., and Gaspari, V., 2006, Southern Ocean sea-ice extent, productivity and iron flux over the past eight glacial cycles: Nature, v. 440, pp. 491-496.

\footnotetext{
Eric Wolff is a Principal Investigator at the British Antarctic Survey in Cambridge, UK. He specialises in ice cores, particularly their chemistry, and all aspects of late Quaternary climate change. He is the chair of the science group of the European Project for Ice Coring in Antarctica (EPICA), which obtained the Dome $C$ ice core discussed in this article. He is a member of the Steering Committee of the IGBP Past Global Changes (PAGES) project, and he co-leads International Partnerships in Ice Core Sciences (IPICS), which is an ice core planning group.
} 